\title{
PONDOK PESANTREN DALAM RANAH ISLAM DI INDONESIA
}

\author{
Fatkhul Mubin \\ fatkhulmubin90@gmail.com
}

\section{A. PENDAhuluan}

Masyarakat Indonesia mayoritas beragama Islam, prosentasenya mencapai 88\%. Bahkan merupakan jumlah muslim terbesar di dunia. Berkaitan dengan itu pendidikan yang ada di Indonesia tidak hanya di sekolah umum, ataupun di madrasah, melainkan ada juga pondok pensantren. Tetapi masih banyak masyarakat yang belum memehami betul tentang pondok pesantren. Maka dalam makalah ini akan dibahas tentang pondok pesantren, mulai dari pengertian, tujuan, bagaimana karakteristik pondok pesantren, tipologi atau model-model pondok pesantren dan juga dibahas pula tentang sistem pendidikan yang ada dipondok pesantren. Sehingga masyarakat mengenal betul tentang pondok pesantren, dan tidak lagi menganggap sebelah mata tentang pondok pesantren.

\section{A. PEMBAHASAN \\ Pengertian Pondok Pesantren}

Kehadiran kerajaan Bani Umayah menjadikan pesatnya ilmu pengetahuan, sehingga anak-anak masyarakat islam tidak hanya belajar dimasjid tetapi juga pada lembaga-lembaga yaitu "kuttab" (pondok pesantren). Kuttab, dengan karakteristik khasnya, merupakan wahana dan lembaga pendidikan islam yang semula sebagai lembaga baca dan tulis dengan sistem halaqah (sistem wetonan). Pada tahap berikutnya kuttab mengalami perkembangan yang sangat pesat karena dengan didukung oleh dana dari iuran masyarakat serta adanya rencana-rencana yang harus dipatuhi oleh pendidik dan peserta didik.

Di Indonesia istilah kuttab lebih dikenal dengan istilah "pondok pesantren", yaitu suatu lembaga pendidikan islam yang didalamnya terdapat seorang kiai (pendidik) yang mengajar dan mendidik para santri (peserta didik) dengan sarana masjid yang digunakan untuk menyelenggarakan pendidikan terebut, serta didukung adanya pemondokan atau asrama sebagai tempat tinggal para santri. ${ }^{1}$

Dalam kamus besar bahas Indonesia, pesantren diartikan sebagai asrama, tempat santri, atau tempat murid-murid belajar mengaji. Sedangkan secara istilah pesantren adalah lembaga

1 Saihu, S. (2019). RINTISAN PERADABAN PROFETIK UMAT MANUSIA MELALUI PERISTIWA TURUNNYA ADAM AS KE-DUNIA. Mumtaz: Jurnal Studi Al-Quran dan Keislaman, 3(2), 268-279,

Saihu, S. (2019). Pendidikan Pluralisme Agama: Kajian tentang Integrasi Budaya dan Agama dalam Menyelesaikan Konflik Sosial Kontemporer. Jurnal Indo-Islamika, 9(1), 67-90,

Saihu, S. (2019). IMPLEMENTASI MANAJEMEN BALANCED SCORECARD DI PONDOK PESANTREN JAM'IYYAH ISLAMIYYAH TANGERANG SELATAN. Mumtaz: Jurnal Studi Al-Quran dan Keislaman, 3(1), 122.

Saihu, S. (2019). KOMUNIKASI PENDIDIK TERHADAP ANAK BERKEBUTUHAN KHUSUS DI SEKOLAH KHUSUS ASY-SYIFA LARANGAN. Andragogi: Jurnal Pendidikan Islam dan Manajemen Pendidikan Islam, 1(3), 418-440.

Saihu, S., \& Marsiti, M. (2019). PENDIDIKAN KARAKTER DALAM UPAYA MENANGKAL RADIKALISME DI SMA NEGERI 3 KOTA DEPOK, JAWA BARAT. Andragogi: Jurnal Pendidikan Islam dan Manajemen Pendidikan Islam, 1(1), 23-54.

Saihu, S. (2019). KONSEP MANUSIA DAN IMPLEMENTASINYA DALAM PERUMUSAN TUJUAN PENDIDIKAN ISLAM MENURUT MURTADHA MUTHAHHARI. Andragogi: Jurnal Pendidikan Islam dan Manajemen Pendidikan Islam, 1(2), 197-217. 
pendidikan Islam, dimana para santri biasanya tinggal di pondok (asrama) dengan materi pengajaran kitab-kitab klasik dan kitab-kitab umum, bertujuan untuk menguasai ilmu agama Islam secara detail, serta mengamalkannya sebagai pedoman hidup keseharian dengan menekankan pentingnya moral dalam kehidupan bermasyarakat.

\section{Tujuan Pendidikan Pondok Pesantren}

Tujuan pendidikan pesantren menurut Mastuhu adalah menciptakan kepribadian muslim yaitu kepribadian yang beriman dan bertaqwa kepada Tuhan, berakhlak mulia bermanfaat bagi masyarakat atau berhikmat kepada masyarakat dengan jalan menjadi kawula atau menjadi abdi masyarakat mampu berdiri sendiri, bebas dan teguh dalam kepribadian, menyebarkan agama atau menegakkan Islam dan kejayaan umat Islam di tengah-tengah masyarakat dan mencintai ilmu dalam rangka mengembangkan kepribadian Indonesia. Idealnya pengembangan kepribadian yang ingin di tuju ialah kepribadian mukhsin, bukan sekedar muslim.

Sedangkan menurut M.Arifin bahwa tujuan didirikannnya pendidikan pesantren pada dasarnya terbagi pada dua yaitu:

a. Tujuan Khusus

Yaitu mempersiapkan para santri untuk menjadi orang 'alim dalam ilmu agama yang diajarkan oleh Kyai yang bersangkutan serta mengamalkannya dalam masyarakat.

\section{b. Tujuan Umum}

Yakni membimbing anak didik agar menjadi manusia yang berkepribadian Islam yang sanggup dengan ilmu agamanya menjadi mubaligh Islam dalam masyarakat sekitar dan melalui ilmu dan amalnya.

\section{Karakteristik Pondok Pesantren}

Karakteristik atau ciri-ciri umum pondok pesantren adalah

a. Adanya kiai

b. Adanya santri

c. Adanya masjid

d. Adanya pondok atau asrama

Sedangkan ciri-ciri khusus pondok pesantren adalah isi kurikulum yang dibuat terfokus pada ilmu-ilmu agama, misalnya ilmu sintaksis Arab, morfologi arab,hukum islam, tafsir Hadis, tafsir Al-Qur'an dan lain-lain. Dalam penjelasan lain juga dijelaskan tentang ciri-ciri pesantren dan juga pendidikan yang ada didalamnya, maka ciri-cirinya adalah. ${ }^{2}$

2 Saihu, S., \& Rohman, B. (2019). PEMBENTUKAN KARAKTER MELALUI MODEL PENDIDIKAN TRANSFROMATIFE LEARNING PADA SANTRI DI PONDOK PESANTREN NURUL IKHLAS BALI. Edukasi Islami: Jurnal Pendidikan Islam, 8(02), 435-452.

Saihu, S., \& Taufik, T. (2019). PERLINDUNGAN HUKUM BAGI GURU. Al Amin: Jurnal Kajian Ilmu dan Budaya Islam, 2(2), 105-116.

Saihu, S. (2020). KONSEP PEMBAHARUAN PENDIDIKAN ISLAM MENURUT FAZLURRAHMAN. Andragogi: Jurnal Pendidikan Islam dan Manajemen Pendidikan Islam, 2(1), 82-95.

Saihu, S. (2020). ETIKA MENUNTUT ILMU MENURUT KITAB TA'LIM MUTA'ALIM. Al Amin: Jurnal Kajian Ilmu dan Budaya Islam, 3(1), 99-112. 
a. Adanya hubungan akrab antar santri dengan kiainya.

b. Adanya kepatuhan santri kepada kiai.

c. Hidup hemat dan sederhana benar-benar diwujudkan dalam lingkungan pesantren.

d. Kemandirian sangat terasa dipesantren.

e. Jiwa tolong-menolong dan suasana persaudaraan sangat mewarnai pergaulan di pesantren.

f. Disiplin sangat dianjurkan.

g. Keprihatinan untuk mencapai tujuan mulia. Hal ini sebagai akibat kebiasaan puasa sunat, zikir, dan i'tikaf, shalat tahajud dan lain-lain.

h. Pemberian ijazah, yaitu pencantuman nama dalam satu daftar rantai pengalihan pengetahuan yang diberikan kepada santri-santri yang berprestasi.

\section{Pesantren}

Pesantren adalah suatu lembaga pendidikan Islam yang telah tua sekali usianya, telah tumbuh sejak ratusan tahun yang lalu, yang setidaknya memilikii lima unsur pokok, yaitu kiyai, santri, pondok, mesjid dan pengajaran ilmu-ilmu agama. ${ }^{3}$

Dalam menentukan kapan pertama kalinya pesantren berdiri di Indonesia, terlebih dahulu perlu melacak kapan pertama kalinya Islam masuk ke semenanjung nusantara. Terdapat berbagai pendapat mengenai kapan masuknya Islam di Indonesia, ada yang berpendapat semenjak abad ketujuh, namun ada juga yang berpendapat semenjak abad kesebelas. Terlepas dari perdebatan seputar kapan masuknya Islam di Indonesia, namun terjadinya kontak yang lebih intens antara budaya Hindu-Budha dan Islam dimulai sekitar abad ketiga belas ketika terjadi kontak perdagangan antara kerajaan Hindu jawa dengan Kerajaan Islam di Timur Tengah dan India. ${ }^{4}$

Dan penyebaran Islam di Indonesia khususnya di Jawa tidak terlepas dari peran wali songo yang dengan gigih memperjuangkan dan menyebarkan nilai-nilai Islam. ${ }^{5}$

Berdirinya Pesantren pada mulanya juga diprakarsai oleh Wali Songo yang diprakarsai oleh Sheikh Maulana Malik Ibrahim yang berasal dari Gujarat India. Para Wali Songo tidak begitu kesulitan untuk mendirikan Pesantren karena sudah ada sebelumnya Instiusi Pendidikan HinduBudha dengan sistem biara dan Asrama sebagai tempat belajar mengajar bagi para bikshu dan

Saihu, Aziz, A., Mubin, F., \& Sarnoto, A. Z. (2020). Design of islamic education based on local wisdom (An analysis of social learning theories in forming character through ngejot tradition in bali). International Journal of Advanced Science and Technology, 29(6), 1278-1293.

Ronaldo, R., Zulfikar, A., Saihu, Ismail, \& Wekke, I. S. (2020). International relations of the asia pacific in the age of trump. Journal of Environmental Treatment Techniques, 8(1), 244-246.

${ }^{3}$ Haidar Putra Daulay, Dinamika Pendidikan Islam (Bandung : Citapustaka, 2004),113

${ }^{4}$ Faiqah, M.Hum, Nyai, Agen Perubahan di Pesantren ( Jakarta : Kucica, 2003),146-147.

${ }^{5}$ Saihu, M. M., \& Aziz, A. (2020). Implementasi Metode Pendidikan Pluralisme Dalam Mata Pelajaran Pendidikan Agama Islam. Belajea; Jurnal Pendidikan Islam, 5(1), 131-150.

Saihu, M. (2019). Urgensi 'Urf dalam Tradisi Male dan Relevansinya dalam Dakwah Islam di JembranaBali. Jurnal Bimas Islam, 12(1), 173-201.

Saihu, S. (2020). The Effect of Using Talking Stick Learning Model on Student Learning Outcomes in Islamic Primary School of Jamiatul Khair, Ciledug Tangerang. Tarbawi: Jurnal Keilmuan Manajemen Pendidikan, 6(01), 61-68.

Saihu, S. (2020). Pendidikan sosial yang terkandung dalam Surat At-Taubah Ayat 71-72. Edukasi Islami: Jurnal Pendidikan Islam, 9(01), 127-148. 
pendeta di Indonesia ${ }^{6}$. Pada masa Islam perkembangan Islam, biara dan asrama tersebut tidak berubah bentuk akan tetapi isinya berubah dari ajaran Hindu dan Budha diganti dengan ajaran Islam, yang kemudian dijadikan dasar peletak berdirinya pesantren.

Selanjutnya pesantren oleh beberapa anggota dari Wali Songo yang menggunakan pesantren sebagai tempat mengajarkan ajaran-ajaran Islam kepada masyarakat Jawa. Sunan Bonang mendirikan pesantren di Tuban, Sunan Ampel mendirikan pesantren di Ampel Surabaya dan Sunan Giri mendirikan pesantren di Sidomukti yang kemudian tempat ini lebih dikenal dengan sebutan Giri Kedaton. ${ }^{7}$

Keberadaan Wali Songo yang juga pelopor berdirinya pesantren dalam perkembangan Islam di Jawa sangatlah penting sehubungan dengan perannya yang sangat dominan. Wali Songo melakukan satu proses yang tak berujung, gradual dan berhasil menciptakan satu tatanan masyarakat santri yang saling damai dan berdampingan. Satu pendekatan yang sangat berkesesuaian dengan filsafat hidup masyarakat Jawa yang menekankan stabilitas, keamanan dan harmoni. $^{8}$

Pendekaan Wali Songo, yang kemudian melahirkan pesantren dengan segala tradisinya, perilaku dan pola hidup saleh dengan mencontoh dan mengikuti para pendahulu yang terbaik, mengarifi budaya dan tradisi lokal merupakan ciri utama masyarakat pesantren. Watak inilah yang dinyatakan sebagai factor dominan bagi penyebaran Islam di Indonesia. ${ }^{9}$ Selain itu ciri yang paling menonjol pada pesantren tahap awal adalah pendidikan dan penanaman nilai-nilai agama kepada para santri lewat-lewat kitab-kitab klasik. ${ }^{10}$

Persoalan asal usul pesantren secara historis lebih tepat jika dipandang sebagai akibat akulturasi dua tradisi besar Islam dan Hindu-Budha yang saling berinteraksi dan saling memperngaruhi satu sama lain dari pada menerima warisan tradisi yang memposisikan tradisi Islam sebagai tradisi yang pasif. Artinya, pandangan hidup dan pemikiran keagamaan kalangan pesantren tidak begitu saja mewarisi taken for granted kebudayaan Hindu-Budha.

\section{Pesantren Pada Masa Penjajahan}

\footnotetext{
${ }^{6}$ Kafrawi, Pembaharuan Studi Pendidikan Pondok Pesantren Sebagai Usaha Pembentukan Prestasi Kerja dan Pembinaan Kesatuan Bangsa (Jakarta : Cemara Indah, 2004), h. 17

${ }^{7}$ Kafrawi, (Jakarta : Cemara Indah, 2004), 17

8 Aziz, A., \& Saihu, S. (2019). Interpretasi Humanistik Kebahasaan: Upaya Kontekstualisasi Kaidah Bahasa Arab. Arabiyatuna: Jurnal Bahasa Arab, 3(2), 299-214

Saihu, S. (2019). PENDIDIKAN KARAKTER BERBASIS KEARIFAN LOKAL (STUDI DI JEMBRANA

BALI). Edukasi Islami: Jurnal Pendidikan Islam, 8(01), 69-90.

Şahin, C. RELIGIA.

Saihu, S., \& Mailana, A. (2019). Teori pendidikan behavioristik pembentukan karakter masyarakat muslim dalam tradisi Ngejot di Bali. Ta'dibuna: Jurnal Pendidikan Islam, 8(2), 163-176.

Mubin, F. KEADILAN DALAM GENDER: KAJIAN KEPEMIMPINAN WANITA DALAM ISLAM1,

Saihu, M. (2019). Merawat Pluralisme Merawat Indonesia (Potret Pendidikan Pluralisme Agama Di JembranaBali). Deepublish.

Mubin, F. (2019). TAFSIR EMANSIPATORIS: PEMBUMIAN METODOLOGI TAFSIR PEMBEBASAN. Mumtaz: Jurnal Studi Al-Quran dan Keislaman, 3(1), 131-151.

Mubin, F. MODEL-MODEL PEMBELAJARAN BERBASIS MADRASAH DAN KEGIATAN LAIN YANG DIPERLUKAN DI DALAMNYA (FAKTOR PENDUKUNGNYA).

${ }^{9}$ Fahry Ali dan Bahtiar Effendy, Merambah Jalan Baru, Rekontruksi Pemikiran Indonesia Masa Orde baru (Bandung : Mizan, 1990),31

${ }^{10}$ Haidar Putra Daulay, Pendidikan Islam, Dalam Sistem Pendidikan Nasional ,26
} 
Pada zaman penjajahan Belanda, dengan berbagai cara Penjajah berusaha untuk mendiskreditkan pendidikan Islam yang dikelola oleh pribumi termasuk didalamnya Pesantren. Sebab pemerintah colonial mendirikan lembaga pendidikan dengan sistem yang berlaku di barat pada waktu itu, namun hal ini hanya diperuntukkan bagi golongan elit dari masyarakat Indonesia. Jadi ketika itu ada dua alternatif pendidikan bagi bangsa Indonesia.

Sebagian besar sekolah colonial diarahkan pada pembentukan masyarakat elit yang akan digunakan untuk mempertahankan supremasii politik dan ekonomi bagi Pemerintah Belanda. Dengan didirikannya lembaga pendidikan atau sekolah yang diperuntukkan bagi sebagian Banga Indonesia tersebut terutama bagi golongan priyayi dan pejabat oleh pemerintah kolonial, maka semenjak itulah terjadi persaingan antara lembaga pendidikan pesantren dengan lembaga pendidikan pemerintah. ${ }^{11}$

Meskipun harus bersaing dengan sekolah-sekolah yang diselenggarakan pemerintah Belanda, pesantren terus berkembang jumlahnya. Persaingan yang terjadi bukan hanya dari segi ideologis dan cita-cita pendidikan saja, melainkan juga muncul dalam bentuk perlawanan politis dan bahkan secara fisik. Hampir semua perlawanan fisik (peperangan) melawan pemerintah colonial pada abad ke-19 bersumber atau paling tidak mendapatkan dukungan sepenuhnya dari pesantren, seperti perang paderi, Diponegoro dan Perang Banjar.

Menghadapi kenyataan demikian menyebabkan pemerintah Belanda diakhir abad ke-19 mencurigai eksistensi pesantren, yang mereka anggap sebagai sumber perlawanan terhadap pemerintah Belanda. Pada tahun 1882 Belanda mendirikan Priesterreden (pengadilan agama) yang salah satu tugasnya mengawasi pendidikan di pesantren. Kemudian dikeluarkan Ordonansi (undang-undang) tahun 1905 mengenai pengawasan terhadap peguruan yang hanya mengajarkan agama (pesantren), dan guru-guu yang mengajar harus mendapatkan izin pemerintah setempat. ${ }^{12}$

Seiring dengan perkembangan sekolah-sekolah Barat modern yang mulai menjamah sebagian masyarakat Indonesia, pesantren pun tampaknya mengalami perkembangan yang bersifat kualitatif, meskipun ruangeraknya senantiasa diawasi dan dibatasi. Ide-ide pembaharuan dalam Islam, termasuk pembaharuan dalam pendidikan mulai masuk ke Indonesia, dan mulai merasuk ke dunia pesantren serta dunia pendidikan Islam lainnya.

Pembaharuan ini menyebabkan sistem modern klasikal mulai masuk ke pesantren, yang sebelumnya masih belum dikenal. Metode halaqah berubah menjadi sistem klasikal, dengan mulai menggunakan kursi, meja dan mengajarkan pelajaran umum. Sementara itu beberapa pesantren mulai memperkenalkan sistem madrasah sebagaimana yang diterapkan pada sekolah umum.

3. Pesantren dan Perkembangan Pada Masa Kemerdekaan Dalam sejarahnya mengenai peran pesantren, dimana sejak masa kebangkitan Nasional sampai dengan perjuangan mempertahankan kemerdekaan RI, pe senantiasa tampil dan telah mampu berpartisipasi secara aktif. Oleh karena itulah setelah kemerdekaan pesantren masih mendapatkan tempat dihati masyarakat. Ki Hajar Dewantara saja selaku tokoh pendidikan

\footnotetext{
${ }^{11}$ Selo Soemarjan, Perubahan Sosial di Yogyakarta,(Gajahmada Pers, Yogyakarta), 278

${ }^{12}$ Amir Hamzah, Pembaharuan Pendidikan dan Pengajaran Islam, (Jakarta, Mulia Offset, 1989). 47
} 
Nasional dan menteri Pendididkan Pengajaran Indonesia yang pertama menyatakan bahwa pondok pesantren merupakan dasar pendidikan nasional, karena sesuai dan selaras dengan jiwa dan kepribadian Bangsa Indonesia. ${ }^{13}$

Begitupula halnya dengan Pemerintah RI, mengakui bahwa pesantren dan madrasah merupakan dasaar pendidikan dan sumber pendidikan nasional, dan oleh karena ituharus dikembangkan, diberi bimbingan dan bantuan. Sejak awal kehadiran pesantren dengan sifatnya yang lentur (flexible) ternyata mampu menyesuaikan diri dengan masyarakat sera memenuhi tuntutan masyarakat. Begitu juga pada era kemerdekaan dan pembangunan sekarang, pesantren telah mampu menampilkan dirinya aktif mengisi kemerdekaan dan pembangunan, terutama dalam rangka pengembangan sumber daya manusia yang berkualitas.

Berbagai inovasi telah dilakukan untuk pengembangan pesantren baik oleh masyarakat maupun pemerintah. Masuknya pengetahuan umum dan keterampilan ke dalam dunia pesantren dalah sebagai upaya mmberikan bekal tambhan agar para santri bila telah menyelesaikan pendidikannya dapat hidup layak dalam masyarakat.

Dewasa ini pondok pesantren mempunyai kecenderungan-kecenderungan baru dalam rangka renovasi terhadap sistem yang selama ini dipergunakan, diantaranya adalah mulai akrab dengan metodologi ilmiah modern, den semakin berorientasi pada pendidikan dan fungsional, artinya terbuka atas perkembangan di luar dirinya. Juga diversifikasi program dan kegiatan makin terbuka dan ketergantungannya pun absolute dengan kiai, dan sekaligus dapat membekali para santri dengan berbagai pengetahuan di luar mata pelajaran agama maupun keterampilan yang diperlukan di lapangan kerja dan juga dapat berfungsi sebagai pusat pengembangan masyarakat. ${ }^{14}$

Dalam rangka menjaga kelangsungan hidup pesantren, pemerintah berusaha untuk membantu mengembangkan pesantren dengan potensi yang dimilinya. Arah perkembangan itu dititik beratkan pada, pertama, peningkatan tujuan institusional pondok pesantren dalam kerangka pendidikan nasional dan pengembangan potensinya sebagai lembaga social pedesaan. Kedua, peningkatan kurikulum dengan metode pendidikan agar efisiensi dan efektifitas pesantren terarah. Ketiga, menggalakkan pendidikan keterampilan di lingkungan pesantren untuk mengembangkan potensi pesantren dalam bidang prasarana social dan taraf hidup masyarakat, dan yang terakhir, menyempurnakan bentuk pesantren dengan madrasah menurut keputusan tiga menteri tahun 1975 tentang peningkatan mutu pendidikan pada madrasah.

Akhir-akhir ini pesantren mempunyai kecenderungan-kecenderungan yang tampaknya ditujukan untuk meningkatkan mutu penyelenggaraan pendidikan yang ada, sebagaimana telah dikemukaakan terdahulu. Pertumbuhan dan perkembangan pesantren di Indonesia sepertinya cukup mewarnai perjalanan sejarah Pendidikan Islam di Indonesia. Kendatipun demikian

${ }^{13}$ Alamsyah Ratu Prawiranegara, Pembinaan Pendidikan Agama, (Jakarta, Depag. RI,) 41.

${ }^{14}$ Rusli Karim, Pendidikan Islam di Indonesia dalam Transformasi Sosial ( Yogyakarta: Tiara Wacana, 1991),134 
pesantren dengan berbagai kelebihannya, juga tentunya tidak akan dapat menghindar dari segala kritik dan kekurangannya.

\section{B. Dinamika Pesantren}

1. Dinamika Keilmuan dan Pendidikan

Pada awalnya berdirinya, pesantren merupakan media pembelajaran yang sangat simple. Tidak ada klasifikasi kelas, tidak ada kurikulum, juga tidak ada aturan yang baku di dalamnya. Sebagai media pembelajaran keagamaan, tidak pernah ada kontrak atau permintaan santri kepada kiai untuk mengkajikan sebuah kitab, apalagi mengatur secara terperinci materi-materi yang hendak diajarkan. Semuanya bergantung pada kiai sebagai poros sistem pembelajaran pesantren. Mulai dari jadwal, metode, bahkan kitabyang hendak diajarkan, semua merupakan wewenang seorang kiai secara penuh. ${ }^{15}$

Tidak seperti lembaga pendidikan lain yang melakukanperekrutan siswa pada waktu-waktu tertentu, pesantren selalu membuka pintu lebar-lebar untuk paa calon santri kapan pun juga. Tak hanya itu, pondok pesantren juga tidak pernah menentukan batas usia untuk siswanya. Siapapun dan dalam waktu kapanpun yang berkeinginan unuk memasuki pesantren, maka kiai akan selalu welcome saja.

Dua model pembelajaran yang terkenal pada awal mula berdirinya pesantren adalah model sistem pembelajaran wetonan non klasikal dan sistem sorogan. Sistem wetonan/bandongan adalah pengajian yang dilakukan oleh seorang kiai yang diikuti oleh santrinya dengan tidak ada batas umur atau ukuran tingkat kecerdasan. Sistem pembelajaran model ini, kabarnya merupakan metode yang diambil dari pola pembelajaran ulama Arab. Sebuah kebiasaan pengajian yang dilakukan di lingkungan Masjid al-Haram. Dalam sistem ini, seorang kiai membacakan kitab, sementara para santri masing-masing memegang kitab sendiri dengan mendengarkan keterangan guru untuk mengesahi atau memaknai Kitab Kuning.

Lain dengan pengajian wetonan, pengajian sorogan dilakukan satu persatu, dimana seorang santri maju satu persatu membaca kitab dihadapan kiai untuk dikoreksi kebenarannya. Pada pembelajaran sorogan ini, seorang santri memungkinkan untuk berdialo dengan kiai mengenai masalah-masalah yang diajarkan. Sayangnya banyak menguras waktu dan tidak efesien sehingga diajarkan pada santri-santri senior saja.

Pada dasarnya, dalam pesantren tradisional, tinggi rendahnya ilmu yang diajarkan lbih banyak tergantung pada keilmuan kiai, daya terima santri dan jenis kitab yang digunakan. Kelemahan dari sistem ini adalah tidak adanya perjenjangan yang jelas dan tahapan yang harus diikui oleh santri. Juga tidak ada pemisahan antara santri pemula dan santri lama. Bahkan seorang kiai hanya mengulang satu kitab saja untuk diajarkan pada santrinya. ${ }^{16}$

Pada abad ke tujuh belasan, materi pembelajaran pesantren didominasi olehmateri-materi ketahuidan. Memang pada waktu itu ajaran ketauhidan dan ketasaufan menduduki urutan yang paling dominant. Belakangan, sejalan dengan banyaknya para ulama yang berguru ketanah suci, materi yang diajarkannya pun bervariasi.

\footnotetext{
${ }^{15}$ Amin Haedani,dkk, Pesantren Dalam Cakrawala Modern (Jakarta: Diva Pustaka, 2004), 80

${ }^{16}$ Amin Haedani, dkk, Pesantren Dalam Cakrawala Modern,82
} 
Baru pada awal abad kedua puluhan ini, unsur baru berupa sistem pendidikan klasikal mulai memasuki pesantren. Walaupun beberapa pesantren telah menggunakan kurikulum Barat, namun banyak juga pesantren-pesantren yang menolak menggunakan sistem ini. Bagi mereka, sistem klasikal adalah pengaruh yang diambil dari sekolah-sekolah yang dibentuk oleh Pemerintah kolonial Belanda. Kelas dalam sistem pendidikan ini adalah sejumlah pelajaran yang diberikan pada ruang dan waktu yang sama, dengan mata pelajaran yang sama pula. Lembaga pendidikan ini mengenal adanya kelas yang berjenjang. Dan dipesantren dikenal dengan sistem madrasah.

Pada mulanya kiai merupakan fungsionaris tunggal dalam pesantren. Semenjak berdirinya madrasah dalam lungkkungan pesantren inilah, diperlukan sejumlah guru-guru untuk mengajarkan berbagai macam jenis pelajaran baru yang tidak semuanya dikuasai oleh kiai. Sehingga peran guru menjadi penting karena kemampuan yang dimilikinya dari pendidikan diluar pesantren. Dan sejak saat itu kiai tidak menjadi fungsionaris tunggal dalam pesantren.

Mengikuti perkembangan zaman, beberapa pesantren mulai memasukkan pelajaran keterampilan sbagai salah satu materi yang diajarkan. Ada keterampilan berternak, bercocok tanam, menjahit berdagang dan lain sebagainya. Disisi lain ada juga pesantren yang cenderung mengimbangi dengan pengetahuan umum. Seperti tercermin dalam madrasah yang disebut dengan "modern" dengan menghapuskan pola pembelajaran wtonan, sorogan dan pembacaan kitab-kitab tradisional. Dnngan mengadopsi kurikulum modern, pesantren yang terakhir ini lebih mengutamakan penguasaan aspek bahasa.

2. Pengaruh Dan Eksistensi Pesantren

Pada abad ke-18, nama pesantren sebagai lembaga pendidikan rakyat menjadi begitu berbobot, terutama berkenaan dengan perannya dalam menyebarkan ajaran Islam. Pada masa itu berdirinya pesantren senantiasa ditandai dengan "perang nilai" antara pesantren yang akan berdiri dengan masyarakat sekitar, yang selalu dimenangkan oleh pihak pesantren, sehingga pesantren diterima untuk hidup dimasyarakat dan kemudian menjadi panutan. ${ }^{17}$ Bahkan kehadiran pesantren dengan santri yang banyak dapat menghidupkan ekonomi masyarakat sehingga dapat memakmurkan masyarakat sekitar.

Selain itu pesantren juga memiliki hubungan erat dengan pejabat sekitar. Kiprah kiai dalam menumpas para perusuh mendapat perhatian besar dari pejabat setempat hingga raja. Tak jarang para Raja mengirim putra-putrinya untuk belajar pada kiai tertentu, dan sebagai bentuk penghormatan, pesantren dibebaskan dari pajak tanah. Pada waktu itu kiai terkenal dengan kesaktiannya, makanya seringkali para Raja mohon bantuan manakala kerajaan menghadapi kekacauan. Hal ini seperti yang dilakukan Pakubuwono yang meminta kiai Agung Muhammad Besari untuk membantunya dalam usaha menghalau musuh.

Terpengaruh dengan adat hindu dimana posisi biksu mendapatkan kasta yang pertama, maka begitu juga dalam kacamata masyarakat Jawa. Orang-orang ynag berada di pesantren -baik kiai maupun santri- mendapatkan tempat yang tinggi dalam stratifikasi masyarakat. Bahkan tak jarang para Raja menikahkan anak-anak mereka dengan para kiai tersohor, sehingga menggabungkan dua strata tertinggi dimasyarakat sekaligus. Hal ini seperti Kiai Kasan Besari yang menjadi menantu Pakubuwono II.

\footnotetext{
${ }^{17}$ Zamakhsari Dhofier, Shtudi tentang Pandang Hidup Kiai (Jakarta : LP3ES, 1994).9
} 
Walaupun kehidupan asketis yang luar biasa terjadi dalam dunia pesantren waktu itu, namun demikian tidak dapat dipungkiri peran yang luar biasa pada masa penjajahan. Dimana jarang sekali sebuah pesantren yang berkompromi dengan penjajahan. Pesantren selalu menjadi basis pejuangan mengusir penjajahan, dimana para pemuda yang ingin maju kemedan pertempuran slalu berkumpul didalamnya untuk melakukan "isian dan gemblengan". Dalam hal ini kita tidak akan lupa dengan kasus Pangeran Diponegoro. Begitu mengakarnya peran ulama/kiai dalam masyarakat -khususnya Jawa, sehingga tak jarang yang menimbulkan mitosmitos dibalik perjuangan pahlawan kemerdekaan. Seperti adanya sosok Kiai Seibi Angin dibalik perjuangan heroic Jaka Sembung. ${ }^{18}$

Akhir abad ke-19, lembaga pesantren semakin berkembang secara cepat dengan adanya sikap non-kooperatif ulama terhadap kebijakan "politik etis" pemerintah kolonial Belanda. Sikap non-kooperatif dan silent opposition para ulama itu kemudian ditunjukkan dengan mendirikan pesantren di daerah-daerah yang jauh dari kota untuk menghindari intervensi yang dilakukan pemerintah colonial serta memberi kesempatan kepada rakyat yang belum memperoleh pendidikan.

Sebagai lembaga pendidikan yang berumur sangat tua ini, pesantren dikenal sebagai media pendidikan yang menampung seluruh jenis strata masyarakat. Lebih jauh pesantren pada waktu itu sedah membuat lembaga pendidikan umum yang didalamnya tidak hanya mengajarkan agama saja. Bisa dikatakan bahwa pesantren pada waktu itu merupakan lembaga alternative kontra dari pendidikan colonial yang hanya diperuntukkan bagi kalangan ningrat saja.

Fakta sejarah membuktikan, betapa kalangan pesantren sangat intensif melakukan perlawanan terhadap segala perilaku budaya dan ideologi maupun politik yang dikhawatirkan akan merongrong ideology yang mereka yakini. Sebut saja seperti pendirian Nahdatul Ulama yang dimotori oleh orang-orang pesantren. Sikap ini juga ditunjukkan dengan pertentangan antara orang-orang pesantren vis a vis gerakan komunis. Alasan yang dikumandangkan orangorang pesantren bahwa gerakan tersebut membahayakan keberagamaan masyarakat di Indonesia. Pada fase menjelang kemerdekaan juga bisa dilihat bagaimana para kiai dan santri untuk menolak habis-habisan budaya "saikere" yaitu membungkuk sembilan puluh derajat untuk menghormati matahari sebagai dewa bangsa Jepang. Akibatnya kiai ternama seperti Kh. Hasyim Asy'ari mendekam di penjara. ${ }^{19}$

Pesantren-ulama/kiai-santri biasanya memiliki hubungan yang cukup erat dengan masyarakat sekelilingnya. Bahkan tradisi yang berlaku didunia pesantren ini pun berlaku dalam dunia luar pesantren. Hal ini dapat terjadi denngan undangan dari masyarakat kepada kiai untuk menghadiri acara tertentu atau dari para alumni pesantren yang menyebar kedaerah-daerah untuk menyebarkan ilmu yang telah didapatkannya dipesantren. Seperti pada peringatan maulid Nabi, Nuzul al-Qur'an, walimah al-ursy, pengajian dan lain sebagainya.

\footnotetext{
${ }^{18}$ Supriyadi, Kiai, Priyai di Masa Transisi (Surakarta: Pustaka Cakra, 2001).

${ }^{19}$ Tim Penyusun, ke-Nu-an, Ahlussunnah Wali Songo al-jama'ah (Semarang : CV Wicaksana, 1990) h. 35
} 
Dari saling berkelindannya kiai-pesantren-santri ini tentunya memiliki pengaruh besar dalam masyarakat. Seorang santri yang baru ke pesantren satu tahun saja, ketika pulang, dikampungnya akan diperlakkukan layaknya seorang kiai oleh masyarakat dii tempat ia tinggal. Maka tak jarang masyarakat karena kecintaan mereka terhadap pesantren banyak memberikan shadaqah, infaq, waqaf dan amal jariyah lainnya dengan ikhlas untuk perkembangan pesantren.

\section{Pesantren di Tengah Arus Globalisasi}

Seiring dengan bergulirnya alur modernisasi, politik global mengalami rekonfigurasi disepanjang lintas-batas kultural. berbagai masyarakat dan Negara yang memiliki kemiripan kebudayaan akan saling bergandengan. Sementara mereka yang berada di wilayah kebudayaan yang berbeda akan memisah dengan sendirinya.

Berhadapan dengan globalisasi dan ancaman kuatnya benturan peradaban, maka tak mungkin pesantren masih bertahan dengan pola pembelajaran lama. Tuntutan masyarakat global adalah profesionalisme, penguasaan ilmu pengetahuan, teknologi serta etos kerja yang tinggi. Maka karena itulah watak profesionalitas dan penguasaan teknologi dan pengetahuan yang standar, diperlukan di pondok pesantren. Jika tidak tentunya pesantren harus siap-siap digilas oleh laju zaman, ditinggalkan orang karena telah usang dan tak layak pakai. Karena itu diharapkan pesantren harus semakin adaptif terhadap perkembangan kamajuan zaman. Atas dasar itu peluang pesantrean sebagai lembaga Pendidikan Islam yang akan menciptakan manusia seutuhnya akan semakin terbuka. ${ }^{20}$

Jika kita mengorelasikan benturan peradaban sebagaimana yang diramalkan Huntington, maka sesungguhnya konflik yang paling mudah menyebar dan sangat penting sekaligus berbahaya bukanlah konflik antar kelas sosial, antar golongan kiai dengan golongan miskin atau antara kelompok kekuatan ekonomi lainnya, akan tetapi konflik antara orang-orang yang memiliki etnis budaya yang berbeda. Pertikaian antar suku dan konflik-konflik antar etnis dalam peradaban- akan senantiasa terjadi.

Dalam hal semacam ini ada beberapa hal yang perlu dijadikan catatan dunia pesantren, yaitu:

1. pertama, konflik yang rawan terjadi pada dunia pesantren sendiri adalah masalah persoalan aliran dan keagamaan. Maka, sebagai antisipasi terhadap terjadinya konflik tersebut, pesantren hendaknya menyosialisasikan semangat inklusifitas.

2. Kedua, berhadapan dengan derasnya arus informasi yang terus mengalir dengan berbagai ragam, pola hidup dan budaya yang ditawarkan. Maka, mau tidak mau, pihak pesantren harus mempersiapkan mental, hingga tidak mudah larut dengan budaya besar. Sekalligus tidak serta merta menutup dengan budaya yang terus menerus hadir. Bersikap kritis dan kreatif merupakan sesuatu yang tidak bisa dinafikan.

3. Ketiga, boleh jadi ramalan Huntington tentang adanya konflik antar peradaban tersebut benar, namun juga tidak menutup kemungkinan bahwa kemungkinan konflik tersebut mampu dihindari. Salah satu caranya adalah dengan mengerahkan kreativitas masyarakat dalam menjembatani dan memfasilitasi hubungan antara berbagai macam masyarakat yang berbeda-beda. Dengan demikian akan mampu mengikat perasaan emosional

\footnotetext{
${ }^{20}$ Haidar, Pendidikan Islam, 36
} 
antarmereka dan akhirnya mampu meminimalisir konflik tersebut dan peran ini harus mampu dilakukan oleh pesantren.

\section{PENUTUP}

Pesantren dipadang sebagai lembaga pendidikan Islam tertua di Indonesia yang didirikan oleh para ulama (Kiai : Jawa). Pesantren didirikan dalam rangka mendidik masyarakat untuk memahami dan melaksanakan ajaran Islam, dengnan menekankan pentignya moral keagamaan sebagai pedoman hidup. Pengertian tertua, karena pesantren adalah lembaga yang telah lama hidup dan masih tetap eksis hingga saat ini walaupun telah banyak berubah dari bentuk awal mula berdirinya dari berbagai bidangnya. Bahkan pesantren telah menjadi bagian yang mendalam dari sistem kehidupan sebagian besar umat islam di Indonesia dan turut mewarnai dinamika bangsa Indonesia.

Demikianlah makalah ini kami tulis, semoga dapat bermanfaat dan menjadi masukan berarti bagi dunia pendidikan khususnya pesantren, terutama sebagai bahan diskusi pada mata kuliah Pendidikan Islam dalam Sistem Pendidikan Nasional. Kepada Allah saya berserah diri sambil berharap selalu mendapat taufik dan hidayah darinya. Wallahu a'lam.

\section{DAFTAR PUSTAKA}

Ali, Fahry dan Bahtiar Effendy, Merambah Jalan Baru, Rekontruksi Pemikiran Indonesia Masa Orde Baru.( Bandung : Mizan, 1990)

Ali, Fahry dan Bahtiar Effendy, Merambah Jalan Baru, Rekontruksi Pemikiran Indonesia Masa Orde Baru.( Bandung : Mizan, 1990)

Aziz, A., \& Saihu, S. (2019). Interpretasi Humanistik Kebahasaan: Upaya Kontekstualisasi

Kaidah Bahasa Arab. Arabiyatuna: Jurnal Bahasa Arab, 3(2), 299-214

Daulay, Haidar Putra. Dinamika Pendidikan Islam.( Bandung : Citapustaka, 2004)

Dhofier, Zamakhsari, Tradisi Pesantren, Shtudi tentang Pandang Hidup Kiai. (Jakarta : LP3ES, 1994)

Faiqah, Nyai, Agen Perubahan di Pesantren.( Jakarta : Kucica, 2003)

Haedani, Amin dkk, Panorama, Pesantren Dalam Cakrawala Modern. (Jakarta: Diva Pustaka, 2004)

Hamzah, Amir, Pembaharuan Pendidikan dan Pengajaran Islam(Jakarta ,Mulia Offset, 1989)

Kafrawi, Pembaharuan Studi Pendidikan Pondok Pesantren Sebagai Usaha Pembentukan Prestasi Kerja dan Pembinaan Kesatuan Bangsa .( Jakarta : Cemara Indah, 2004)

Mubin, F. (2019). TAFSIR EMANSIPATORIS: PEMBUMIAN METODOLOGI TAFSIR PEMBEBASAN. Mumtaz: Jurnal Studi Al-Quran dan Keislaman, 3(1), 131-151.

Mubin, F. KEADILAN DALAM GENDER: KAJIAN KEPEMIMPINAN WANITA DALAM ISLAM1,

Mubin, F. MODEL-MODEL PEMBELAJARAN BERBASIS MADRASAH DAN KEGIATAN LAIN YANG DIPERLUKAN DI DALAMNYA (FAKTOR PENDUKUNGNYA).

Ronaldo, R., Zulfikar, A., Saihu, Ismail, \& Wekke, I. S. (2020). International relations of the asia pacific in the age of trump. Journal of Environmental Treatment Techniques, 8(1), 244-246.

Şahin, C. RELIGIA. 
Saihu, Aziz, A., Mubin, F., \& Sarnoto, A. Z. (2020). Design of islamic education based on local wisdom (An analysis of social learning theories in forming character through ngejot tradition in bali). International Journal of Advanced Science and Technology, 29(6), 12781293.

Saihu, M. (2019). Urgensi 'Urf dalam Tradisi Male dan Relevansinya dalam Dakwah Islam di Jembrana-Bali. Jurnal Bimas Islam, 12(1), 173-201.

Saihu, M. (2019). Merawat Pluralisme Merawat Indonesia (Potret Pendidikan Pluralisme Agama Di Jembrana-Bali). Deepublish.

Saihu, M. M., \& Aziz, A. (2020). Implementasi Metode Pendidikan Pluralisme Dalam Mata Pelajaran Pendidikan Agama Islam. Belajea; Jurnal Pendidikan Islam, 5(1), 131-150.

Saihu, S. (2019). IMPLEMENTASI MANAJEMEN BALANCED SCORECARD DI PONDOK PESANTREN JAM'IYYAH ISLAMIYYAH TANGERANG SELATAN. Mumtaz: Jurnal Studi Al-Quran dan Keislaman, 3(1), 1-22.

Saihu, S. (2019). KOMUNIKASI PENDIDIK TERHADAP ANAK BERKEBUTUHAN KHUSUS DI SEKOLAH KHUSUS ASY-SYIFA LARANGAN. Andragogi: Jurnal Pendidikan Islam dan Manajemen Pendidikan Islam, 1(3), 418-440.

Saihu, S. (2019). KONSEP MANUSIA DAN IMPLEMENTASINYA DALAM PERUMUSAN TUJUAN PENDIDIKAN ISLAM MENURUT MURTADHA MUTHAHHARI. Andragogi: Jurnal Pendidikan Islam dan Manajemen Pendidikan Islam, 1(2), 197-217.

Saihu, S. (2019). PENDIDIKAN KARAKTER BERBASIS KEARIFAN LOKAL (STUDI DI JEMBRANA BALI). Edukasi Islami: Jurnal Pendidikan Islam, 8(01), 69-90.

Saihu, S. (2019). Pendidikan Pluralisme Agama: Kajian tentang Integrasi Budaya dan Agama dalam Menyelesaikan Konflik Sosial Kontemporer. Jurnal Indo-Islamika, 9(1), 67-90,

Saihu, S. (2019). RINTISAN PERADABAN PROFETIK UMAT MANUSIA MELALUI PERISTIWA TURUNNYA ADAM AS KE-DUNIA. Mumtaz: Jurnal Studi Al-Quran dan Keislaman, 3(2), 268-279,

Saihu, S. (2020). ETIKA MENUNTUT ILMU MENURUT KITAB TA'LIM MUTA'ALIM. $A l$ Amin: Jurnal Kajian Ilmu dan Budaya Islam, 3(1), 99-112.

Saihu, S. (2020). KONSEP PEMBAHARUAN PENDIDIKAN ISLAM MENURUT FAZLURRAHMAN. Andragogi: Jurnal Pendidikan Islam dan Manajemen Pendidikan Islam, 2(1), 82-95.

Saihu, S. (2020). Pendidikan sosial yang terkandung dalam Surat At-Taubah Ayat 7172. Edukasi Islami: Jurnal Pendidikan Islam, 9(01), 127-148.

Saihu, S. (2020). The Effect of Using Talking Stick Learning Model on Student Learning Outcomes in Islamic Primary School of Jamiatul Khair, Ciledug Tangerang. Tarbawi: Jurnal Keilmuan Manajemen Pendidikan, 6(01), 61-68.

Saihu, S., \& Mailana, A. (2019). Teori pendidikan behavioristik pembentukan karakter masyarakat muslim dalam tradisi Ngejot di Bali. Ta'dibuna: Jurnal Pendidikan Islam, 8(2), 163-176.

Saihu, S., \& Marsiti, M. (2019). PENDIDIKAN KARAKTER DALAM UPAYA MENANGKAL RADIKALISME DI SMA NEGERI 3 KOTA DEPOK, JAWA BARAT. Andragogi: Jurnal Pendidikan Islam dan Manajemen Pendidikan Islam, 1(1), 2354.

Saihu, S., \& Rohman, B. (2019). PEMBENTUKAN KARAKTER MELALUI MODEL PENDIDIKAN TRANSFROMATIFE LEARNING PADA SANTRI DI PONDOK 
PESANTREN NURUL IKHLAS BALI. Edukasi Islami: Jurnal Pendidikan Islam, 8(02), 435-452.

Saihu, S., \& Taufik, T. (2019). PERLINDUNGAN HUKUM BAGI GURU. Al Amin: Jurnal Kajian Ilmu dan Budaya Islam, 2(2), 105-116. 